\title{
Effect of Dietary Supplementation of MOS and Protexin on Production Performance and Immune Response in Broilers
}

\author{
S.K. Soren, B.S. Barmase, S.S. Kullu, Reetu and S.K. Pradhan* \\ Dept. of Animal Science, NMCA, Navsari Agricultural University, Gujarat, India \\ *Corresponding author
}

\begin{abstract}
A B S T R A C T
The study was conducted to evaluate the growth performance, immune organs weight and

\begin{tabular}{|l|}
\hline Ke y w or d s \\
Mannan \\
Oligosaccharide \\
(MOS), Probiotic \\
(Protexin)
\end{tabular}
hematological changes in broiler chickens on supplementation of Mannan-oligosaccharide (MOS) and Protexin. 240 day-old broiler chicks were supplied with control diets (A), MOS (B), Protexin (C) and symbiotic (MOS+Protexin-D). The MOS and probiotic was supplied 1000 and $100 \mathrm{~g} / \mathrm{ton}$ in starter and 500 and $75 \mathrm{~g} / \mathrm{ton}$ in finisher diet, respectively. The growth performance viz., body weight, body weight gain and feed conversion ratio were obtained weekly up to the $6^{\text {th }}$ week of age whereas the hematological and organ weight was obtained on $4^{\text {th }}$ and $6^{\text {th }}$ week of age. The average body weights and weight gain from the $3^{\text {rd }}$ to $6^{\text {th }}$ week of age were improved $(\mathrm{P}<0.01)$ in same trend among groups $\mathrm{B}, \mathrm{C}$ and $\mathrm{D}$ as compared to $\mathrm{A}$ (control). The average feed intake (FI) and feed conversion ratio (FCR; P<0.01) at 6 weeks was significantly better in MOS, protexin and symbiotic fed groups than control. Bursa had significantly $(\mathrm{P}<0.05)$ higher weight in symbiotic group. No differences were observed in blood parameters and haemato-biochemical studies. It concluded the MOS and protexin supplementation may improve the growth with improved FCR and immune status of the broiler chickens with optimum economy.
\end{abstract}

\section{Introduction}

The huge demand of poultry meat is pressurizing the industry to produce cheap and good quality meat. Even though the challenge of well nourished nutrition for the accelerating growth and hygienic meat production is a burning issue. Poultry meat is today the major source of meat in India. Its share in total meat consumption is above 28 percent, as against 14 percent fifteen years ago. Therefore, cost effective production for the availability of cheap and reliable poultry meat to fulfill the present demand is one of the necessary requirement. Livability and improved growth performance through proper utilization of nutrients from the supplied feed would be the primary objective. The supplementation of growth promoter may provide natural health and maintenance of growth to broiler birds which overcome the early chicks' mortality and economic loss on broiler rearing is the primary aim for the broiler industry.

The present study was based on objective to evaluating the effect of MOS and Probiotic 
(protexin) on the growth performance and changes occurred in hemato-biology of broiler chickens. Mannan oligosaccharide is "a nondigestible food ingredient that beneficially affects the host by selectively stimulating the growth and/or activity of one or many naturally present or introduced bacterial species in the intestine" while the probiotic is "a live microbial feed supplement, which beneficially affects the host animals by improving their intestinal balances" Fuller (1989).

\section{Materials and Methods}

A total of two hundred and forty day-old straight run commercial broiler chicks were reared under four dietary treatments in a complete randomized design viz., without supplement diet - A, with Mannan oligosaccharide (MOS) supplement- B, with Probiotic (Protexin) supplement - C and Symbiotic (MOS+Probiotic) - D with 60 chicks in each group subdivided into 3 replicates having 20 chicks in each replicate. The experimental birds were wing banded, weighed individually and reared on deep litter system bedded with saw dust as a litter material. Uniform environmental conditions were provided to all the treatment groups throughout the experimental period. The feed and water were provided ad-lib to all the experimental birds.

The diets were prepared as BIS (2000) specifications in three different phase feeding practice. The supplementation of MOS to the basal diet was at the rate of $1 \mathrm{~kg} /$ tone in starter and $0.5 \mathrm{~kg} /$ tone in finisher ration and the Protexinwas @ $100 \mathrm{~g} /$ tone in basal ration for 0-3weeks and $75 \mathrm{~g} /$ tone for 4-6weeks. The diets were maintained isonitrogenous and isocaloric.

The formulated diets were chemically analyzed and it was carried out as per
A.O.A.C. (1995). The nutrient composition in broiler ration is expressed on dry matter (DM) basis. The weekly body weight, body weight gain, feed consumption and feed conversion ratio were recorded till the 42 days of age in the broiler. Blood and serum sampling was done by cutting the jugular vein which was collected in sterile with and without EDTA containing vials. Group wise mortality was recorded and economic of production has been calculated with the help of computer. The data was analyzed by applying Factorial Completely Randomized Design (FCRD) for weekly body weights, feed consumption and feed efficiency while blood parameter was analyzed by one way ANOVA.

The per cent composition of basal diets for pre-starter, starter and finisher are presented in Table 1.

\section{Results and Discussion}

\section{Live body weights and body weight gain}

The data obtained revealed that the body weight has significantly increases from the 3-4 week of age. At the end of sixth week, the final average body weights were recorded in control group (A) $1619.80 \pm 11.54 \mathrm{~g}$ followed by mannan oligosaccharides group (B) $1846.02 \pm 10.28 \mathrm{~g}$, Probiotic group (C) $1832.13 \pm 11.34 \mathrm{~g}$ and symbiotic group (D) $1864.38 \pm 11.10 \mathrm{~g}$ with the mean value of $1790.58 \pm 8.46 \mathrm{~g}$. The mean body weight gains for all the treatment groups were 262.39 $\pm 6.87,300.17 \pm 7.80,297.83 \pm 7.72$ and $303.43 \pm 7.91 \mathrm{~g}$, respectively in 0-6 weeks of age which is progressive increment from 3-4 week of age. There was non-significant difference found between the treatment groups receiving the diets, MOS, probiotic and its combination. However, these treatments were highly significant $(\mathrm{P}<0.01)$ from control group. The maximum body weights were observed in diet receiving symbiotic (D) group 
followed by MOS (B), probiotic (C) and lowest in control (A) group (Table 2). It indicated that, supplementation of mannan oligosaccharide and probiotic combination in broilers diet were effectively increasing higher body weights among all treatment groups. The Victor et al., (1993) have reported 0.1 \% MOS in diet could significantly improve the live body weight compared to control. Kumprecht and Zobac (1997) determined the effect of MOS in feed mixture has more efficiently improved the growth performance of broilers.

The treatment receiving diet supplemented with MOS + Protexin (D) showed highest body weight in all the consecutive weeks as compared to the other treatments. The birds receiving the diet with MOS + Protexin resulted in 15.63 per cent improvement in overall weight gain followed by MOS 14.40 per cent and 13.51 per cent improvement in weight gain in Protexin (C) group as compared to control. However, within treatments weekly weight gain obtained was approximately similar among the treatments B, C and D but showed highly significant difference with the control group. Pupovac et al., (1998) reported that there was 7-12\% improvement in daily gain of weight by the addition of MOS in the feed of broilers. Sabiha et al., (2005) found significant increase in body weight gain on probiotic supplementation at 0.025 per cent up to 6 weeks of age in broilers. Anjum et al., (2005) also supported the present findings, that the Protexin supplementation @ 100 g/ton of feed in starter and $50 \mathrm{~g} / \mathrm{ton}$ in finisher feed had shown significantly $(\mathrm{P}<0.05)$ better weight gain than that of control diet. The prebiotic increases the availability of minerals specially calcium, magnesium, zinc and iron. Therefore, it can be inferred from this results that MOS, probiotic (Protexin) and its combination as a feed supplement results better in respect of body weight gain.

\section{Feed consumption}

The significant differences in mean feed consumption were observed in the present study. However, the highest feed consumption was recorded in treatment supplied with symbiotic (MOS + probiotic) diet. The treatment B and C fed MOS supplemented and Probiotic supplemented diet showed no significant changes with each other in feed consumption but significantly varied from the control group (Table 3).

Similarly, the combination of MOS and Protexin (D) was highly significant $(\mathrm{P}<0.01)$ in the feed consumption than other treatments. The birds receiving diet with MOS + probiotic had 10.60 per cent more feed intake followed by 7.30 per cent in MOS and 7.18 per cent in probiotic as compared to control group.

The data justifies Prebiotic in combination with Probiotic effects synergistically, prebiotic modifies the intestinal flora by their inherent ability to get selectively fermented the feed ingredients which enhance the utilization of feed ingredient whereas probiotic have an advantages to improve digestibility and utilization of nutrients. Huang et al., (2005) reported the significant improvement in feed intake with probiotic supplement in broilers. But contrary to this, Yalcinkaya et al., and Gunal et al., (2008 and 2006) reported prebiotic and protexin supplementation was non-significant on the feed intake.

\section{Feed efficiency}

The average feed conversion ratio irrespective of treatments were $1.92 \pm 0.02,1.86 \pm 0.01$, $1.92 \pm 0.02$ and $1.91 \pm 0.03$, respectively at $6^{\text {th }}$ weeks of age among the treatment control, MOS group, Protexin group and symbiotic group. The data shown, variation was significant $(\mathrm{P}<0.01)$ in consecutive weeks (Table 4). 
Table.1 Weekly body weight of MOS, probiotic and combination (MOS + probiotic) supplemented feed in broiler chicken

\begin{tabular}{|c|c|c|c|c|c|c|c|}
\hline \multirow[t]{2}{*}{ Treatments } & \multicolumn{7}{|c|}{ Weeks } \\
\hline & DOH & I & II & III & IV & V & VI \\
\hline A - Control & $45.47 \pm 0.45$ & $134.58 \pm 1.00$ & $304.50 \pm 3.02$ & $527.23 \pm 4,49^{a}$ & $834.77 \pm 1.31^{\mathrm{a}}$ & $1245.55 \pm 12.17^{\mathrm{a}}$ & $1619.80 \pm 11.54^{a}$ \\
\hline B - MOS & $45.00 \pm 0.49$ & $140.77 \pm 1.11$ & $325.77 \pm 3.85$ & $575.40 \pm 4.60^{\mathrm{b}}$ & $960.20 \pm 4.11^{b}$ & $1438.12 \pm 11.40^{b}$ & $1846.02 \pm 0.28^{b c}$ \\
\hline C - Probiotic & $45.17 \pm 0.49$ & $143.03 \pm 0.79$ & $326.83 \pm 3.76$ & $574.72 \pm 4.68^{b}$ & $958.20 \pm 3.76^{b}$ & $1433.33 \pm 11.80^{b}$ & $1832.13 \pm 11.34^{b}$ \\
\hline $\begin{array}{l}\text { D - MOS + } \\
\text { Probiotic }\end{array}$ & $43.92 \pm 0.51$ & $144.48 \pm 0.97$ & $331.28 \pm 4.27$ & $583.60 \pm 3.26^{b}$ & $985.33 \pm 5.18^{b}$ & $1463.63 \pm 12.78^{b}$ & $1864.38 \pm 11.10^{c}$ \\
\hline Level of Sig. & NS & NS & NS & $\mathrm{P}<0.01$ & $\mathrm{P}<0.01$ & $\mathrm{P}<0.01$ & $\mathrm{P}<0.01$ \\
\hline
\end{tabular}

Table.2 Weekly weight gain of MOS, probiotic and combination (MOS + probiotic) supplemented feed in broiler chicken

\begin{tabular}{|l|c|c|c|c|c|c|}
\hline \multicolumn{1}{|c}{ Treatments } & \multicolumn{5}{c|}{ Weeks } \\
\cline { 2 - 7 } & DOH to I & I to II & II to III & III to IV & IV to V & V to VI \\
\hline A - Control & $89.12 \pm 1.10$ & $169.92 \pm 3.22$ & $222.73 \pm 5.22$ & $307.53 \pm 4.39^{\mathrm{a}}$ & $410.78 \pm 12.20^{\mathrm{a}}$ & $374.25 \pm 14.73^{\mathrm{a}}$ \\
\hline B - MOS & $95.77 \pm 1.13$ & $185.00 \pm 4.02$ & $249.63 \pm 6.01$ & $384.80 \pm 5.73^{\mathrm{b}}$ & $477.92 \pm 11.66^{\mathrm{b}}$ & $407.90 \pm 13.06^{\mathrm{b}}$ \\
\hline C - Probiotic & $97.87 \pm 0.96$ & $183.80 \pm 3.90$ & $247.88 \pm 6.17$ & $383.48 \pm 5.82^{\mathrm{b}}$ & $475.13 \pm 12.75^{\mathrm{b}}$ & $398.80 \pm 12.34^{\mathrm{b}}$ \\
\hline D - MOS + Probiotic & $100.57 \pm 1.09$ & $186.80 \pm 4.29$ & $252.32 \pm 5.39$ & $401.73 \pm 5.62^{\mathrm{b}}$ & $478.30 \pm 12.70^{\mathrm{b}}$ & $400.75 \pm 15.19^{\mathrm{b}}$ \\
\hline Level of Sig. & NS & NS & NS & $\mathrm{P}<0.01$ & $\mathrm{P}<0.01$ & $\mathrm{P}<0.01$ \\
\hline
\end{tabular}

Table.3 Weekly feed consumption of MOS, probiotic and its combination supplemented feed in broiler chicken

\begin{tabular}{|c|c|c|c|c|c|c|}
\hline \multirow{2}{*}{ Treatments } & \multicolumn{6}{|c|}{ Weeks } \\
\hline & DOH to I & I to II & II to III & III to IV & IV to V & V to VI \\
\hline A - Control & $117.65 \pm 0.74$ & $310.10 \pm 3.99$ & $510.10 \pm 2.86$ & $752.75 \pm 5.98$ & $958.76 \pm 13.91$ & $834.41 \pm 3.23^{\mathrm{a}}$ \\
\hline B - MOS & $112.27 \pm 2.27$ & $320.28 \pm 4.21$ & $546.72 \pm 6.04$ & $815.48 \pm 6.87$ & $1002.78 \pm 7.42$ & $940.53 \pm 14.77^{\mathrm{d}}$ \\
\hline C - Probiotic & $115.17 \pm 2.34$ & $357.73 \pm 9.09$ & $579.40 \pm 11.79$ & $822.37 \pm 10.54$ & $988.27 \pm 9.63$ & $870.89 \pm 24.57^{b}$ \\
\hline D - MOS + Probiotic & $113.93 \pm 3.12$ & $359.05 \pm 7.68$ & $567.28 \pm 12.01$ & $841.12 \pm 11.23$ & $\begin{array}{c}1034.12 \pm \\
17.47\end{array}$ & $937.35 \pm 3.50^{\mathrm{c}}$ \\
\hline Level of Sig. & NS & NS & NS & NS & NS & $\mathrm{P}<0.01$ \\
\hline
\end{tabular}


Table.4 Weekly feed conversion ratio of MOS, probiotic and combination (MOS + probiotic) supplemented feed in broiler chicken

\begin{tabular}{|l|c|c|c|c|c|c|c|}
\hline \multirow{2}{*}{ Treatments } & \multicolumn{9}{c|}{ Weeks } & \multicolumn{2}{c|}{ Overall mean } \\
\cline { 2 - 8 } & DOH to I & I to II & II to III & III to IV & IV to V & V to VI & DOH-VI \\
\hline A - Control & $1.32 \pm 0.04$ & $1.82 \pm 0.05$ & $2.29 \pm 0.03$ & $2.45 \pm 0.01$ & $2.33 \pm 0.13$ & $2.23 \pm 0.09$ & $2.07 \pm 0.11^{\mathrm{a}}$ \\
\hline B - MOS & $1.17 \pm 0.01$ & $1.73 \pm 0.02$ & $2.19 \pm 0.02$ & $2.12 \pm 0.01$ & $2.10 \pm 0.01$ & $2.31 \pm 0.03$ & $1.94 \pm 0.10^{\mathrm{b}}$ \\
\hline C - Probiotic & $1.18 \pm 0.03$ & $1.95 \pm 0.06$ & $2.34 \pm 0.07$ & $2.14 \pm 0.02$ & $2.08 \pm 0.01$ & $2.18 \pm 0.07$ & $1.98 \pm 0.10^{\mathrm{b}}$ \\
\hline D - MOS + Probiotic & $1.13 \pm 0.04$ & $1.92 \pm 0.05$ & $2.25 \pm 0.07$ & $2.09 \pm 0.04$ & $2.16 \pm 0.03$ & $2.34 \pm 0.11$ & $1.98 \pm 0.11^{\mathrm{b}}$ \\
\hline Level of Sig. & NS & NS & NS & NS & NS & NS & P<0.01 \\
\hline
\end{tabular}

Table.5 Blood biochemistry of MOS, probiotic and combination (MOS + probiotic) supplemented feed in broiler chicken

\begin{tabular}{|c|c|c|c|c|c|c|}
\hline \multicolumn{7}{|c|}{ Total Erythrocyte count (10\%/cumm) } \\
\hline Weeks & $\mathbf{A}$ & B & $\mathbf{C}$ & D & Pooled Mean & Level of Sig. \\
\hline $4^{\text {th }} \mathbf{W k}$ & $2.70 \pm 0.13$ & $3.17 \pm 0.11$ & $2.92 \pm 0.18$ & $3.64 \pm 0.11$ & $3.00 \pm 0.20$ & NS \\
\hline $6^{\text {th }} \mathbf{W k}$ & $2.62 \pm 0.06$ & $2.97 \pm 0.06$ & $3.10 \pm 0.06$ & $3.61 \pm 0.04$ & $2.94 \pm 0.06$ & NS \\
\hline \multicolumn{7}{|c|}{ - Total Leukocyte count $\left(10^{3} /\right.$ cumm $)$} \\
\hline $4^{\text {th }} \mathbf{W k}$ & $11.02 \pm 0.49$ & $13.77 \pm 0.51$ & $11.42 \pm 0.60$ & $12.67 \pm 0.38$ & $12.34 \pm 0.51$ & NS \\
\hline $6^{\text {th }} \mathrm{Wk}$ & $11.83 \pm 0.43$ & $13.55 \pm 0.57$ & $13.18 \pm 0.53$ & $11.60 \pm 0.50$ & $12.92 \pm 0.49$ & NS \\
\hline \multicolumn{7}{|c|}{ Packed Cell Volume (\%) } \\
\hline $4^{\text {th }}$ Week & $27.57 \pm 0.75$ & $27.33 \pm 1.15$ & $26.17 \pm 1.33$ & $29.67 \pm 0.95$ & $27.17 \pm 1.06$ & NS \\
\hline $6^{\text {th }}$ Week & $31.50 \pm 1.36$ & $28.67 \pm 0.95$ & $31.00 \pm 1.53$ & $33.33 \pm 1.43$ & $30.08 \pm 1.27$ & NS \\
\hline \multicolumn{7}{|c|}{ Serum Glucose $(\mathrm{mg} / \mathrm{dl})$} \\
\hline $4^{\text {th }}$ Week & $225.45 \pm 3.06$ & $221.47 \pm 1.58$ & $231.32 \pm 1.36$ & $238.91 \pm 1.75$ & $229.29 \pm 1.93$ & NS \\
\hline $6^{\text {th }}$ Week & $236.67^{\mathrm{a}} \pm 5.36$ & $255.78^{\mathrm{ab}} \pm 4.41$ & $271.97^{\mathrm{b}} \pm 5.45$ & $274.58^{\mathrm{b}} \pm 3.97$ & $259.75 \pm 4.80$ & $\mathrm{p}>0.01$ \\
\hline \multicolumn{7}{|c|}{ Serum total protein $(\mathrm{g} / \mathrm{dl})$} \\
\hline $4^{\text {th }}$ Week & $3.40 \pm 0.02$ & $3.41 \pm 0.03$ & $3.49 \pm 0.01$ & $3.48 \pm 0.03$ & $3.39 \pm 0.02$ & NS \\
\hline $6^{\text {th }}$ Week & $4.02 \pm 0.04$ & $3.91 \pm 0.05$ & $3.89 \pm 0.02$ & $4.02 \pm 0.06$ & $3.90 \pm 0.09$ & NS \\
\hline
\end{tabular}


Table.6 Hematological parameters of MOS, probiotic and combination (MOS + probiotic) supplemented feed in broiler chicken

\begin{tabular}{|c|c|c|c|c|c|}
\hline \multicolumn{6}{|c|}{ Hemoglobin \% (g/dl). } \\
\hline Weeks & $\begin{array}{c}\text { A } \\
\text { Control }\end{array}$ & $\begin{array}{c}\text { B } \\
\text { MOS }\end{array}$ & $\begin{array}{c}\text { C } \\
\text { Probiotic }\end{array}$ & $\begin{array}{c}\text { D } \\
\text { MOS + Probiotic }\end{array}$ & Level of Sig. \\
\hline $4^{\text {th }}$ Week & $9.30 \pm 0.38$ & $10.07 \pm 0.19$ & $9.72 \pm 0.38$ & $9.68 \pm 0.25$ & NS \\
\hline $6^{\text {th }}$ Week & $9.65 \pm 0.33$ & $9.88 \pm 0.35$ & $9.79 \pm 0.17$ & $10.15 \pm 0.30$ & NS \\
\hline \multicolumn{6}{|c|}{ Total Erythrocyte count $\left(10^{6} /\right.$ cumm $)$} \\
\hline $4^{\text {th }}$ Week & $2.70 \pm 0.13$ & $3.17 \pm 0.11$ & $2.92 \pm 0.18$ & $3.24 \pm 0.11$ & NS \\
\hline $6^{\text {th }}$ Week & $2.62 \pm 0.06$ & $2.97 \pm 0.06$ & $3.10 \pm 0.06$ & $3.31 \pm 0.14$ & NS \\
\hline \multicolumn{6}{|c|}{ Total Leukocyte count $\left(10^{3} /\right.$ cumm $)$} \\
\hline $4^{\text {th }}$ Week & $11.02 \pm 0.49$ & $13.77 \pm 0.51$ & $11.42 \pm 0.60$ & $12.67 \pm 0.38$ & NS \\
\hline $6^{\text {th }}$ Week & $11.83 \pm 0.43$ & $13.55 \pm 0.57$ & $13.18 \pm 0.53$ & $11.60 \pm 0.50$ & NS \\
\hline \multicolumn{6}{|c|}{ Packed Cell Volume (\%) } \\
\hline $4^{\text {th }}$ Week & $27.57 \pm 0.75$ & $27.33 \pm 1.15$ & $26.17 \pm 1.33$ & $29.67 \pm 0.95$ & NS \\
\hline $6^{\text {th }}$ Week & $31.50 \pm 1.36$ & $28.67 \pm 0.95$ & $31.00 \pm 1.53$ & $33.33 \pm 1.43$ & NS \\
\hline \multicolumn{6}{|c|}{ Serum Glucose (mg/dl) } \\
\hline $4^{\text {th }}$ Week & $223.23 \pm 2.05$ & $230.75 \pm 3.08$ & $222.42 \pm 1.36$ & $238.91 \pm 1.75$ & NS \\
\hline $6^{\text {th }}$ Week & $248.05 \pm 6.44^{b}$ & $271.97 \pm 5.55^{\mathrm{a}}$ & $271.97 \pm 5.45^{\mathrm{a}}$ & $274.58 \pm 3.97^{\mathrm{a}}$ & \\
\hline \multicolumn{6}{|c|}{ Serum Total Protein (g/dl) } \\
\hline $4^{\text {th }}$ Week & $3.40 \pm 0.02$ & $3.41 \pm 0.03$ & $3.49 \pm 0.01$ & $3.48 \pm 0.03$ & NS \\
\hline $6^{\text {th }}$ Week & $4.02 \pm 0.04$ & $3.91 \pm 0.05$ & $3.89 \pm 0.02$ & $4.02 \pm 0.06$ & NS \\
\hline
\end{tabular}

Table.7 Immune organs weight (g/100g BW) in 6th week broiler chicken fed with MOS and probiotic supplemented feeds

\begin{tabular}{|c|c|c|c|}
\hline Treatment & \multicolumn{3}{|c|}{ Immune Organs } \\
\cline { 2 - 4 } & Spleen & Bursa & Thymus \\
\hline A & $0.08 \pm 0.04$ & $0.21^{\mathrm{a}} \pm 0.04$ & $\mathbf{0 . 1 3} \pm \mathbf{0 . 0 2}$ \\
\hline B & $0.07 \pm 0.04$ & $0.24^{\mathrm{a}} \pm 0.06$ & $\mathbf{0 . 1 5} \pm \mathbf{0 . 0 6}$ \\
\hline C & $0.08 \pm 0.11$ & $0.23^{\mathrm{a}} \pm 0.09$ & $\mathbf{0 . 1 4} \pm \mathbf{0 . 0 3}$ \\
\hline D & $0.07 \pm 0.04$ & $0.29^{\mathrm{b}} \pm 0.04$ & $\mathbf{0 . 1 5} \pm \mathbf{0 . 0 5}$ \\
\hline Level of sig. & $\mathrm{NS}$ & $\mathrm{P}<0.05$ & $\mathrm{NS}$ \\
\hline
\end{tabular}


Table.8 Per cent composition of experimental diets

\begin{tabular}{|l|c|c|c|}
\hline \multirow{2}{*}{\multicolumn{1}{|c|}{ Ingredients }} & \multicolumn{3}{|c|}{ Composition at different phase (\%) } \\
\cline { 2 - 4 } & $\begin{array}{c}\text { Pre-starter } \\
(0-1 \mathrm{wks})\end{array}$ & $\begin{array}{c}\text { Starter } \\
(2-3 \mathrm{wks})\end{array}$ & $\begin{array}{c}\text { Finisher } \\
\text { wks })\end{array}$ \\
\hline Maize, Yellow & 52.00 & 53.00 & 57.60 \\
\hline Soyabean meal, DOC & 41.50 & 39.50 & 34.40 \\
\hline Limestone powder (LSP) & 1.50 & 1.50 & 1.55 \\
\hline Dicalcium phosphate (DCP) & 1.50 & 1.50 & 1.50 \\
\hline Common Salt & 0.30 & 0.30 & 0.30 \\
\hline Vitamin-premix & 0.15 & 0.15 & 0.15 \\
\hline Trace min.mix & 0.05 & 0.05 & 0.05 \\
\hline DL-methionine & 0.15 & 0.15 & 0.15 \\
\hline Edible Oil & 2.85 & 3.85 & 4.30 \\
\hline Nutrient composition analyzed & & & \\
\hline Crude Protein, \% & 22.87 & 22.04 & 20.20 \\
\hline Crude Fibre, \% & 03.10 & 05.24 & 05.90 \\
\hline Ether Extract, \% & 04.12 & 04.23 & 04.51 \\
\hline Nitrogen Free Extract, \% & 64.41 & 64.57 & 66.34 \\
\hline Total Ash, \% & 04.45 & 04.28 & 04.55 \\
\hline ME Kcal/kg (calculated) & 2997 & 3067 & 3139 \\
\hline
\end{tabular}

*Vitamin Supplements includes (per Quintal of feed): Vitamin A, $\mathrm{B}_{2}, \mathrm{D}_{3}, \mathrm{~K}-10 \mathrm{~g}$, B-care plus- 25g, DOT (coccidiostat)- $50 \mathrm{~g}$, Cholin chloride- $50 \mathrm{~g}$, Antioxidant- 15g.

Whereas, within the treatments, the groups treated with MOS (prebiotic), Protexin (probiotic) and symbiotic (MOS + Protexin), the variation was negligible and nonsignificant but all treatment groups significantly $(\mathrm{P}<0.01)$ influenced as compared to control. However, the group treated with MOS numerically showed slightly better feed efficiency than Protexin and symbiotic treated groups.

The dietary supplementation of prebiotic and probiotic significantly results better feed efficiency of chickens. Hooge (2004), observed that MOS diets shown comparatively better results to improve FCR than control diets.

\section{Hematology and Blood biochemistry}

Blood profile (Table 6) TEC, TLC, PCV and serum total protein did not differ among the supplemented groups but serum glucose level on 6 week of age increased $(p<0.01)$ in all the supplemented groups as compared to control.

\section{Immune organ response}

Significant increased $(p<0.05)$ weight of immune organ bursa in symbiotic group shown improved immune response may be due to combination effect protexine and probiotic whereas other organs spleen and thymus did not statically differed (Table 7).

\section{Mortality}

The overall mortality during the experimental period was 2.08 per cent. Only five birds were died out of two hundred and forty experimental birds and out of these five two from probiotic and three from control diet 
were died, i.e. about 5 per cent in control and 2 per cent in probiotic supplemented group (Table 8). The mortality did not show any resemblance with the dietary treatment levels. The cause of mortality was yolk-sac disease and heat stress. The present results are agreed with Parks et al., (2001) who reported MOS, supplemented diets had no mortality rate in male turkeys. Ceylan et al., (2003) also reported that prebiotic and probiotic supplemented groups did not show any significant difference in mortality rate in broiler chicks.

In conclusion, the present result concluded that the supplementation of MOS and probiotic in the broiler diet can improve the performance by proper utilization of feed ingredients and efficient development intestinal microflora. This accelerates the growth mechanisms. Addition to this, it improve the health status of birds and reduces mortality by preventing the growth of harmful organisms, also enhances the growth of beneficial organisms. Furthermore, MOS can reduce the production cost and increase profit margin through low mortality and better weight gain in broiler birds.

\section{Acknowledgement}

The author acknowledges Poultry Science Department and Animal Nutrition Department, Post Graduate Institute of Veterinary and Animal Sciences, Akola, to facilitate the necessary requirements for the completion of research programme and to Indian council of Agricultural Research, New Delhi for their financial assistance.

\section{References}

Anjum M. I., A. G. Khan, A. Azim and M. Afzal (2005). Effect of dietary supplementation of multi-strain Probiotic on broiler growth performance. Pakistan Vet. J., 25(1): 2529.

AOAC, (1995). Official Method of Analysis, $16^{\text {th }}$ Edn. Association of official analytical chemists, Washington D.C.

BIS (2000). Buro of Indian Standards, Nutrients requirement for poultry, Manak. Bhavan New Delhi, India.

Ceylan, N., I. Ciftci and Z. llhan (2003). The effects of some alternative feed additives for antibiotic growth promoters on the performance and gut microflora of broiler chicks. Turk. Veterinerlik. Ve. Hayavancik. Dergisi. 27(3): 292-294.

Fuller, R. (1989). A review: Probiotics in man and animals. J. Appl. Bacterial. 66: 305378

Gunal M., G. Yayli, O. Kaya, N. Karahan and O. Sulak (2006). The effect of antibiotic growth promoter, probiotic or organic acid supplementation on performance intestinal microflora and tissue of broilers. Indian J. Poult. Sci. 5(2): 149155.

Hooge, D. M. (2004). Meta-analysis of Broiler Chicken Pen Trials Evaluating Dietary Mannan Oligosaccharide. International J. Poult. Sci.3(3): 163-174.

Huang, R. L. Yin, G. Y. Wu, Y. G. Zhang, B. Wang, J. H. He and X. Z. Nie (2005). Effect of dietary oligochitosan supplementation on ileal digestibility of nutrients and performance in broilers. Poult. Sci. 34(9): 1383-1388.

Kumprecht, I. and P. Zobac (1997). The effect of mannan oligosaccharide in feed mixture on the performance of chicken broilers. Zivocisna Vyroba. 42(3): 75-82. Parks, C. W., J. L. Grimes, P. R. Ferket and A. S. Fairchild (2001). The effect of mannan oligosaccharide, bambermycins and Virginiamycin on performance of large white male market turkeys. Poult. Sci. 80: 718-723.

Pupavac S, Sinovec Z, Jerkovi (1998). Rezultati korioenja manan- 
oligosaharida u ishrani brojlera, Nauka u ivinarstvu, 1-2, 459-71.

Sabiha M. K. A., V. K. Elizabeth and A. Jalaludeen (2005). Effect of supplementation of probiotic on the growth performance of broiler chickens. Indian J. Poult. Sci. 40(1): 73-75.

Victor, G. S., O. Raphael, W. Selamawit and H. H. Dande (1993). The use of Saccharomyces cerevisiae to suppress the effect of aflatoxicosis in broiler chicken. Poult. Sci. 72: 1867-1872.

Yalcinkaya, llkay, Tulin Gungor, Mechmet Basalan and Everen Erdem. (2008). mannan oligosaccharide (MOS) from Saccharomyces cerevisiae in broiler; Effect on performance and blood biochemistry. Turk. J. Vet. Ani. Sci. 32(1): 43-48.

\section{How to cite this article:}

Soren, S.K., Barmase, B.S., Kullu, S.S., Reetu and Pradhan, S.K. 2018. Effect of Dietary Supplementation of MOS and Protexin on Production Performance and Immune Response in Broilers. Int.J.Curr.Microbiol.App.Sci. 7(12): 2192-2200.

doi: https://doi.org/10.20546/ijcmas.2018.712.249 